\title{
Delhi 2005
}

\author{
By Ron Holloway
}

Fall 2005 Issue of KINEMA

\section{CINEFAN FESTIVAL OF ASIAN CINEMA IN DELHI 2005}

Back in 1999, when the First Cinefan Festival of Asian Cinema was launched in New Delhi by publicist Aruna Vasudev, together with UNESCO friends and with the support of Delhi Chief Minister Sheila Dikshit, the program numbered only 27 Asian films. Seven years later, in partnership with entrepreneur Neville Tuli and his Indian auction house for popular art and Hollywood-Bollywood memorabilia, the re-christened $7^{\text {th }}$ Ocean's Cinefan Festival of Asian Cinema (15-24 July 2005) could offer its public of feast of 121 Asian films from 35 countries. The films were presented on four screens in the Siri Fort Complex, plus an extra venue at the Alliance Française. The evening shows were nearly all sold out.

How did Delhi become one of the biggest and most representative festivals of Asian cinema? Only Pusan in Korea and Filmex in Tokyo are comparable oases of Asian film art. "In the beginning we simply wanted to introduce the Indian public to quality Asian films," said Aruna Vasudev. "That was in 1987, when I pleaded for a new section in the International Film Festival of India (IFFI) - namely, a series of outstanding Asian films." In 1988, Vasudev founded Cinemaya, an Asian film journal to champion Asian directors at festivals around the world. Cinemaya developed quickly into the best Asian film journal on the circuit, featuring reports from correspondents on directors, trends, festivals, and a regular national focus on an Asian filmland.

In 1990, the Cinemaya-Team - Aruna Vasudev, Indu Shrikent, Latika Padgaonkar - founded the Network for the Promotion of Asian Cinema (NETPAC), whose juries at various international film festivals awarded a prize to an Asian entry. Cinefan, in 1999, was the natural outgrowth of NETPAC, a festival devoted exclusively to Asian cinema. It also happens to be the only film festival in the world that awards a prize to a film critic. This year, it was Donald Ritchie, the American journalist based in Tokyo and author of several books on Japanese cinema.

Cinefan 2005 was composed of twelve sections: Asian Competition (15 entries), Indian Competition (12 entries), Asian Frescoes (24 new Asian films), Indian Ocean (12 new Indian films), Arabesque (10 films from the Near East and Africa), Cross Cultural Encounters (6 Asian co-productions with western producers), Fortissimo Films Carte Blanche (8 Asian films in the Dutch distribution company), Fonds Sud (8 French funded Asian films), Hou Hsiao-hsien (5 films) and Martial Arts Retrospectives (11 films), Satyajit Ray Tribute ( 5 films), and Special Screenings ( 5 awarded films).

The festival opened with Wang Xiaoshuai's Qing hong (Shanghai Dreams, China), the first Chinese entry in Cannes to be officially supported by the Chinese government. In Shanghai Dreams a family secretly searches to find a way back to their native city. Back in the 1960s, the father was forced to leave Shanghai to work in the underdeveloped Guizhou Province, where he and his family are ridiculed for their urban ways. The only way back home is via an illegal transport in the middle of the night. Asked whether the film would be guaranteed a release in China, Wang responded with a shrug: "Probably." Then added: "But not my previous film, Drifters (Cannes 2000, Un Certain Regard), the story of young people who just hang around without much desire to find their place in society."

For the closing night gala Cinefan presented Buddhadeb Dasgupta's Kaalpurush (Memories in the Mist, India) by the renown Bengali writer, poet, and film director. More tone poem than narrative drama, Memories in the Mist links the thoughts of two men, father and son, who share similar painful experiences in the past with their wives. Surreal images underscore the clash between traditional ways and modern life styles. Pretty much the same cultural conflict was explored by Satyajit Ray in his classic Pather Panchali (India, 1955), the film chosen as the centerpiece of the Delhi festival. Thanks to the American Academy of Arts and Sciences, a restored print in pristine black-and-white was presented to a grateful Cinefan public on the occasion of the film's $50^{\text {th }}$ anniversary. 
Cinefan had the good fortune to draw upon entries previously seen at Berlin and Cannes. Indeed, three competition entries at this year's Berlinale were booked for presentation in Delhi. In Tsai Ming-liang's Tian bian yi duo yun (The Wayward Cloud, Taiwan-France), a controversial film to say the least, the director explores the loneliness of the erotic scene, particularly the inability to communicate on any human level. In Gu Changwei's Kongque (Peacock, China), the first directed film by well known cameraman, the setting is shortly after the Cultural Revolution of the 1960s. A sensitive young girl tries with all her might to break the hold of her uncaring parents and find a way out of the restrains of provincial life. Gu Changwei is best remembered for his camera work on the films of Zhang Yimou (Red Sorghum, Golden Bear, Berlinale 1988) and Chen Kaige (Farewell, My Concubine, Golden Palm, Cannes 1993).

In Yoji Yamada's Kakuschi ken -oni no tsume (The Hidden Blade, Japan), another Berlinale entry, a Samurai fights for his honour in the twilight of the Samurai era, Japan in the middle of the $19^{\text {th }}$ century. To some extent, The Hidden Blade is the sequel to Yamada's Tasogare Seibei(The Twilight Samurai), programmed at the 2002 Berlinale, by way of the popular short stories on this samurai period penned by Shuhei Fujisawa. The Hidden Blade also fit to the Martial Arts retrospective programmed at Cinefan - old and new films from Hong Kong, Korea, China, Taiwan, Japan, Indonesia, France, and the United States.

"This series is an attempt to link arthouse cinema and mainstream movies on the Asian production scene," said Aruna Vasudev. And she is certainly right when one considers the impact made on the international scene by such box office hits as Zhang Yimou's Hero and Ang Lee's Crouching Tiger, Hidden Dragon. Of particular interest for the Delhi audience were the classic martial arts films by King $\mathrm{Hu}$ (Hong Kong) and Kenji Misumi (Japan). After all, Kenji Misumi's Zatoichi kessho-tabi (Fight, Zatoichi, Fight, Japan 1964), the tale of a legendary blind samurai fighting for justice, was the forerunner of Takeshi Kitano's popular remake, Zatoichi (Japan 2003).

Cinefan cineastes showed up early for the screenings of four key Cannes entries. In Vimukthi Jayasundara's Sulanga enu pinisa (The Forsaken Land, Sri Lanka-France), a debut feature awarded a share of the Caméra d'Or Prize at Cannes, a veil of fear and anxiety still hangs over an empty idyllic landscape shortly after the civil war. The designers of the soundtrack on The Forsaken Land - Alberto Crespo-Ocampo, Frank Desmoulins, Nicolas Naegelen - were collectively awarded a Special Jury Prize by the Asian Jury at Delhi. "It is the sequence of sounds that brings the film's world-view into focus," ran the jury declaration. "The sensitive recording and re-recording of sounds, music, and words, their pitch and volume, their timbre, their position could not have been more precisely realized." All of which does not in the least take away from the artistic contribution of "the director Vimukthi Jayasundara, who in the first place envisioned the extraordinary juxtaposition and movement of sound effect, dialogue and music."

Similarly, Kôhei Oguri's Umoregi (The Buried Forest, Japan) is best described as a camera tour-de-force in its depiction of bizarre events in a village high in the mountains after a rainstorm. When young girls find what appears to be the remains of a forest buried centuries ago under volcanic ash, they let their imaginations run away with them. As for the villagers, they couldn't be less interested in wild tales of fantasy. "The images we see and the images we want to see are compounded," said Kôhei Oguri in an interview. In other words, everyone sees images differently. Oguri's first film after a nine-year pause, The Buried Forest comes across as a meditation on the beauty of nature.

From Cannes came two political documents. In Im Sang-Soo's Geuddae geusaramdeul (The President's Last Bang, South Korea) the assassination of Korean President Park Chung-Hee on 26 October 1979) is chronicled over a 24-hour period. As Park, who ruled the country with a heavy hand for 18 years, was killed by the head of the KCIA (the CIA of Korea), much has been speculated about the motifs for the assassination. Although few clues are given in The President's Last Bang, the film does captivate as a criminal investigation into the killing of Korean president. It was reported at Delhi that certain cuts were required in the film before a permit for general release in Korea was granted.

Funded by Fonds Sud, Rithy Panh's Les artistes du théâtre brûlé (The Burnt Theatre, Cambodia-France), documents the efforts of a group of Cambodian actors to keep alive the song and dance traditions of their National Theatre after the building that once housed them burnt down ten years ago. Today, the actors, living in poverty, perform mostly for tourists interested only in folklorica. Rithy Panh, who grew up in Cambodia under the Khmer Rouge regime before escaping across the border to Thailand, has devoted his 
filmmaking career to chronicle not only the recent past in Cambodia, but also to throw light on present-day efforts to revive the country's fading cultural heritage. His S21 - La machine de mort Khmère Rouge (S21 The Khmer Rouge Killing Machine, Cambodia-France 2003), documented the horrors of the Khmer Rouge "killing machine" as recorded in the genocide museum at Tuol Sleng in a residential neighbourhood of Phnom Penh. His Les gens d'Angkor (The People of Angkor, France-Cambodia, 2003), shot on the sight of one of the world's great historical sites, pairs the bas-relief portrayals of smiling deities on the monuments with the faces of ordinary people and stone-masons hired to restore the ancestral temple. The Burnt Theatre continues in this vein of exploring a national conscience. Based in Paris, Rithy Panh is currently the President of Fonds Sud Cinema. At Delhi he served on the jury for the Indian Competition.

Jahar Kanungo's Nisshabd (Reaching Silence) was awarded Best Indian Film. In this quaint story of a man in his thirties, a neurotic, who can't stand the noise on the streets of Delhi, the solution appears to be to hightail it to a Bengali village far off the beaten path. This, however, is when the story gets interesting for he meets a sensitive young woman and falls in love. Meanwhile, the villagers begin to feel they have a fanatic living amongst them, which in turn leads to the expected confrontation. The Jury praised the film's "refreshing cinematic language and sensibility - a well realized film that is delightful, funny, poignant, and at the same time thought-provoking." Trina Neelina Banerjee in the role of the village girl received a Best Actress award

Garin Nugroho's Rindui kami padamu (Of Love and Eggs, Indonesia) was awarded Best Film by the Asian Jury. The setting is a bazaar in Jakarta, where a young boy sells duck eggs, a delicacy in Indonesia. The lad, who doesn't particularly like working for the egg-salesman, smashes an egg every chance he gets. The only distraction that takes his mind off his job and mischief is a young girl, who passes by every now and then. At the nearby mosque the children are given dubious lessons in religion by a couple of old cronies, who don't have a clue as to how to apply the Koran to daily life. At prayer time a little girl is preoccupied with the task of defending the prayer-rug next to her own, as this is reserved for a mother, if she should ever show up. Of Love and Eggs is a warming film, full of wit and humour and a dash of irony.

Yangjin's Yi zhi huo naenju (The Black-and-White Milk Cow, China) was awarded the NETPAC Prize. A first feature by a student at the Beijing University, The Black and White Milk Cow is the story of a young man who gives up his studies to return to a village and care for his ailing grandmother. To make ends meet, his uncle arranges for a teaching job, save that the school is practically a ruins. His only payment is a cow that still gives milk. Below the surface of this rural tale runs a second narrative line dealing the spread of AIDS. This is the first time HIV, a tabu theme, has been treated in a Chinese feature film.

Azizollah Hamidnezhad's Ashk-e sarma (Tear of the Cold, Iran) was awarded the FIPRESCI Prize. Set in the far north of Iran, where Kurds and Iranians are sworn enemies, Tear of the Cold depicts the efforts of a sensitive young Iranian soldier to make friends with villagers while he goes about his job of defusing landmines. At the same time, a shepherd girl, who tends her sheep in the freezing war zone, works for the Kurdish resistance. In this story of love and betrayal, it's the convincing performance of Parsa Piroozfar as the caring soldier that adds depth and balance to the political parable. Parsa Piroozfar was awarded Best Actor by the Asian Jury.

The icing on the festival cake were two magnificent five-film retrospectives in honour of a pair of great directors: India's Satyajit Ray (1921-1992) and Taiwan's Hou Hsiao-hsien. The story goes that when Satyajit Ray died in 1992, an estimated million mourners marched in the funeral procession, the greatest outpouring of public grief since the death of Tagore fifty years before. Besides Satyajit Ray's 1955 masterpiece Pather Panchali, Cinefan programmed the Bengali director's Mahanagar (The Big City, 1963, Silver Bear, Berlinale 1964), Charulata (1964, Silver Bear, Berlinale 1965), Seemabaddha (Company Limited, 1971, FIPRESCI Award, Venice 1972), and Sonar Kella (The Golden Fortress, 1974), based on Ray's own novel for a young public with the same title. A stunning tribute, the series well deserves to go on tour.

As for Hou Hsiao-hsien (born 1947), the selection of films focused on a theme that occupied the Taiwanese director the most throughout his career - namely people. "I am very emotional about people," he said in a director's statement. "I don't know why. Only people can move me." Films from the 1980s make the golden years of his career: Fengkuei-lai-te jen (The Boys from Fengkuei, 1983, Grand Prix, Nantes 1984), Tong nien wang shi (The Time to Live and the Time to Die, 1985, FIPRESCI Award, Berlinale 1986), 
Lianlian fengchen (Dust in the Wind, 1986, Kinema Jumpo Award, Tokyo 1989), Beiqing chengshi (A City of Sadness, 1989, Golden Lion, Venice 1989), and Kôĥ̂ Jikô (Café Lumière, Taiwan-Japan 2003), commissioned to commemorate the centenary of Yasujiro Ozu's birth (1903-1963). Often compared with Ozu, although their styles are entirely different, Hou does share with Ozu a profound interest in the human condition.

Last, but not least, the Berlinale Talent Campus (BTC) was back in Delhi for the second time around. Following its broad acceptance at the 2004 Cinefan festival, due largely to the guiding hands of Christine Dorn and Neel Caudhuri, the Campus again invited 50 film students from India, Pakistan, and Sri Lanka to meet for four days with film professionals. Fluent in both German and English, Neel Caudhuri spent six months last year in Berlin in preparation for this year's BTC. If Aruna Vasudev has anything to say about the matter, the Berlinale Talent Campus may become a permanent fixture at Cinefan.

\section{References}

\section{AWARDS}

\section{ASIAN COMPETITION}

Best Film: Rindu kami padamu (Of Love and Eggs, Indonesia), dir Garin Nugroho

Best Actor: Parsa Pirouzfar in Ashk-e sarma (Tear of the Cold, Iran), dir Azizollah Hamidnezhad

Best Actress: Zhang Jingchou in Kongque (Peacock, China), Gu Changwei

Special Jury Prize for Soundtrack: Sulanga enu pinisa (The Forsaken Land, Sri Lanka), dir Vimukthi Jayasundara

\section{INDIAN COMPETITION}

Best Film: Nisshabd (Reaching Silence), dir Jahar Kanungo

Best Actress: Trina Neelina Banerjee in Nisshabd (Reaching Silence), dir Jahar Kanungo

Special Mention: Actress Roopa Ganguly for her presence in Krantikaal (Critical Encounter), dir Sekhar Das

Best Actor: Sabhyasachi Chakraborthy in Nichijapon (After the Night ... Dawn), dir Sandip Ray

Special Jury Prize: Yahaan (Here), dir Soojit Sarkar

\section{OTHER AWARDS}

FIPRESCI (International Critics) Award: Ashk-e sarma (Tear of the Cold, Iran), dir Azizollah Hamidnezhad - Asian Competition

NETPAC (Network for Promotion of Asian Cinema) Award: Yi zhi hua naenju (The Black and White Milk Cow, China), dir Yangjin - Asian Frescoes

Critics Award for Indian Film : Kal: "Yesterday and Tomorrow", dir Ruchi Narain - Asian Competition

\section{Author Information}

Ron HOLLOWAY (1933-2009) was an American critic, film historian, filmmaker and correspondent who adopted Europe as his home in the early fifties and spent much of his life in Berlin. He was an expert on the study of German cinema and against all odds produced, with his wife Dorothea, the journal German Film, keeping us up-to-date with the work of directors, producers and writers and the showing of German films around the world.

In 2007, Ron Holloway and his wife were awarded the Berlinale Camera Award. Ron also received the Bundesverdienstkreuz (German Cross of Merit), Polish Rings, Cannes Gold Medaille, the American Cinema 
Foundation Award, the Diploma for Support of Russian Cinema and an honorary award from the German Film Critics' Association.

Ron was also a valued contributor to Kinema for the past fifteen years. 